\title{
The selection of a standard STR panel for DNA profiling of the African elephant (Loxodonta africana) in Kenya
}

\author{
Julius Kinuthia $\cdot$ Cindy Harper $\cdot$ Shadrack Muya $\cdot$ Charles Kimwele $\cdot$ \\ Amos Alakonya - Anne Muigai · Francis Gakuya - Mercy Mwaniki • \\ Erastus Gatebe
}

Received: 14 May 2014/Accepted: 17 October 2014/Published online: 26 October 2014

(C) The Author(s) 2014. This article is published with open access at Springerlink.com

\begin{abstract}
The African elephant (Loxodonta africana) population in Kenya is declining at an alarming rate due to habitat destruction, human-elephant conflicts and the current escalation of poaching for ivory. This study established a standard protocol for forensic analysis of $L$. africana and their products such as ivory. Three multiplex PCR panels consisting of 17 Short Tandem Repeat markers were selected from 40 markers using bioinformatics tools, amplification and polymorphism. Genotyping was successful and reproducible. This method is efficient, accurate and cost effective and has potential for application in conservation of $L$. africana.
\end{abstract}

Keywords Microsatellites $\cdot$ Standard panel $\cdot$ Forensic analysis - African elephants

Electronic supplementary material The online version of this article (doi:10.1007/s12686-014-0366-6) contains supplementary material, which is available to authorized users.

\author{
J. Kinuthia $(\bowtie) \cdot$ S. Muya · A. Alakonya · A. Muigai · \\ E. Gatebe \\ Jomo Kenyatta University of Agriculture and Technology \\ (JKUAT), Nairobi, Kenya \\ e-mail: jkinuthiam@jkuat.ac.ke \\ C. Harper \\ University of Pretoria, Pretoria, South Africa \\ C. Kimwele \\ University of Nairobi, Nairobi, Kenya \\ F. Gakuya \\ Kenya Wildlife Service, Nairobi, Kenya \\ M. Mwaniki \\ Technical University of Kenya, Nairobi, Kenya
}

Currently there are around 0.5 million vulnerable African elephants with Kenya accounting for about 28,000 (IUCN 2013a, b). In Africa, approximately 25,000 and 22,000 elephants were illegally killed in 2011 and 2012 respectively (CITES 2013; Vira and Ewing 2014). Highly polymorphic microsatellite markers can provide a useful tool for traceability of elephant products to geographic origin (Wasser et al. 2006).

This study evaluated the suitability of 40 published STR markers (Comstock et al. 2000; Archie et al. 2003; Eggert et al. 2000; Nyakaana and Arctander 1998; Nyakaana et al. 2005) for forensic analysis. Initial selection criteria included the removal of 15 imperfect STR markers: FH102, LaT05, LaT07, LaT16, LaT17, LaT26, LA1, LA2, LA4, LafMS07, LafMS08, LafMS09, LafMS10, LafMS11 and LafMS01, to avoid the formation of variant alleles that have no equivalency between fragment length and amplicon sequence (Guichoux et al. 2011). In forensics, perfect motifs are preferred (Gusmao et al. 2006).

The primers were then assessed for hairpin formation and self-annealing using oligocalc ${ }^{\circledR}$ (Kibbe 2007). Primers from seven markers: FH1, FH65, FH40, LAT13, LAT18, LAT25 and LafMSO3 formed hairpins. Four markers were modified using oligocalc ${ }^{\circledR}$ while three markers: FH65, LAT18 and LafMSO3 were excluded because they were difficult to modify. Hairpin loops, if present can reduce the efficiency of the reaction by limiting primer ability to bind to the complementary fragment (Vinay et al. 2000). Primers from three markers: Lat 06, LafMSO4 and LafMSO5 had potential for self-annealing. Two were modified while one, LafMSO4, was excluded due to the position of the complementary base pairs. Details on modification of primers are provided as supplementary material, S1.

The primers' annealing temperature (Ta) was determined using oligocalc ${ }^{\circledR}$. Primers with Ta higher than $60{ }^{\circ} \mathrm{C}$ 


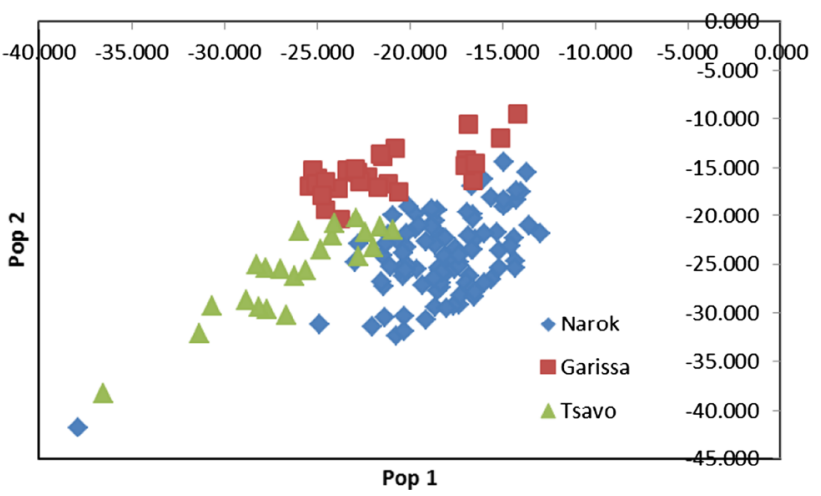

Fig. 1 Showing population assignments into self, closest or distant population, with log-likelihoods as negative values, the highest (least negative) value indicates the most likely population

were modified to standardize the Ta within a range of $5{ }^{\circ} \mathrm{C}$. Three multiplex PCR panels of six, seven and seven primers pairs were designed based on Ta and expected fragment length. The primers were tested for cross annealing using vector NTI 11.1 (Invitrogen, CA, USA) and no cross-annealing occurred. GenBank BLAST searches revealed no alignment with other parts of the elephant genome.

Genomic DNA was extracted from 147 Kenyan elephant samples from Narok (98), Garissa (27) and Tsavo (22) using Qiagen kits. Amplification was first tested in singleplex gradient PCR and later in multiplex PCR. Two Ta of 55 and $58{ }^{\circ} \mathrm{C}$ were chosen as most primers amplified at those temperatures. Biometra PCR calculator (2007) software was used to calculate the quantities of primers, water, Taq DNA polymerase (Thermoscientific, 1U), reaction buffer (Thermoscientific, 1X), magnesium chloride (Thermoscientific, $2.0 \mathrm{mM}$ ) and dNTPs mixes (Thermoscientific, $0.2 \mathrm{mM}$ ) in each multiplex PCR reaction. The cycling parameters were: one cycle of enzyme activation at $95{ }^{\circ} \mathrm{C}$ for $3 \mathrm{~min}$; 35 cycles of denaturation at $94{ }^{\circ} \mathrm{C}$ for $30 \mathrm{~s}$, annealing at 58 or $55^{\circ} \mathrm{C}$ (Table 1) for $1 \mathrm{~min}$, and extension at $72{ }^{\circ} \mathrm{C}$ for $1 \mathrm{~min}$; and a final extension at $72{ }^{\circ} \mathrm{C}$ for 20 min. The success of the multiplex PCR was confirmed by comparing the results with the single-plex and pseudo multiplexed PCR products. Primer modification enhanced co-amplification of primers in the same reaction.

Specificity of the primers was tested by comparative analysis using samples from other species: common zebra, gnu, cow, grant gazelle, dik dik, giraffe, sheep, kongoni, thomson gazelle, goat, impala, lesser kudu, warthog and donkey and no amplification products were obtained indicating species specificity. Fidelity was high as the markers were found to amplify low quality DNA from dung and ivory although better amplification was observed from the biopsy tissue samples. Reproducibility was tested by repeat amplification and by use of different thermocyclers:
GeneAmp ${ }^{\circledR}$ 9,700, GeneAmp ${ }^{\circledR}$ 2,720, veriti ${ }^{\circledR}$ (life technologies), Gene Pro (BIOER Technology) and results were similar for all these instruments.

Genotyping was done using a 3,730 Genetic Analyser ${ }^{\mathrm{TM}}$ (Life Technologies) capillary electrophoresis system with three fluorescent labels (FAM, NED and VIC) and Gene$\mathrm{scan}^{\mathrm{TM}} 500 \mathrm{LIZ}^{\mathrm{TM}}$ standard. The data was analyzed using GeneMapper ${ }^{\circledR}$ version 4.1 (Life Technologies). The number of alleles per locus for the 147 samples ranged from 1 to 20 . The markers: FH 94, LA3 and LafMSO5, had one or two alleles and were excluded from the test, leaving a final list of 17 STR markers: FH1, LA5, FH103, FH60, LaT24, FH39, LafMSO6, LA6, FH19, FH40, FH67, LafMSO2, FH48, LaT08, LaT06, LaT25 and LaT13 (S1). To test the ability of the proposed 17 STR markers in assigning confiscated ivory to source population, the method of Paetkau et al. (1995, 2004) was used. The results showed that 142 individuals (97\%) were correctly assigned into their populations, 4 individuals $(2.7 \%)$ were assigned to the closest neighboring population (Fig. 1) and one individual (0.7 \%) assigned to a more distant population. Three test ivory samples, one from each population were correctly assigned into their source populations. The 17 STR markers could therefore reliably assign confiscated ivory to the source population in Kenya. We recommend the establishment of a DNA database of $L$. africana, with control DNA samples, to provide an opportunity for match determination of confiscated ivory.

Acknowledgments This work was funded by JKUAT and the Commission for Science Technology and Innovation.

Open Access This article is distributed under the terms of the Creative Commons Attribution License which permits any use, distribution, and reproduction in any medium, provided the original author(s) and the source are credited.

\section{References}

Archie EA, Moss CJ, Alberts SC (2003) Characterization of tetranucleotide microsatellite loci in the African savannah elephant (Loxodonta africana africana). Mol Ecol Notes 3:244-246

Biometra company impressum (2007). Biometra calculator software $<$ www.biometra.com/impressum.0.html $>$ Downloaded on14 September 2014

CITES-Convention on International Trade in Endangered Species (2013) New figures reveal poaching for the illegal ivory trade could wipe out a fifth of Africa's Elephants over next decade. $<$ www.cites.org/eng/news>. Downloaded on14 May 2014

Comstock KE, Wasser SK, Ostrander EA (2000) Polymorphic microsatellite DNA loci identified in the African elephant (Loxodonta africana). Mol Ecol 9:1004-1006

Eggert LS, Ramakrishnan U, Mundy NI, Woodruff DS (2000) Polymorphic microsatellite DNA markers in the African elephant (Loxodonta africana) and their use in the Asian elephant (Elephas maximus). Mol Ecol 9:2223-2225 
Guichoux E, Lagache L, Wagner S, Chaumeil P, Lepais O, Lepoittevin C, Malausa T, Revardel E, Salin F, Petit RJ (2011) Current trends in microsatellite genotyping. Mol Ecol Resour 11:591-611

Gusmao L, Butler JM, Carracedo A (2006) DNA Commission of the International Society of Forensic Genetics (ISFG): an update of the recommendations on the use of Y-STRs in forensic analysis. Int J Legal Med 120:191-200

IUCN-International Union for Conservation of Nature (2013a) IUCN Red List of Threatened Species, version 2013.2. <www.iucnred list.org >. Downloaded on14 May 2014

IUCN-International Union for Conservation of Nature (2013b) Elephant database, fifth update on the status of the African elephant under the aegis of the African Elephant Specialist Group. <www.elephantdatabase.org > Downloaded on14 May 2014

Kibbe WA (2007) 'OligoCalc: an online oligonucleotide properties calculator. Nucleic Acids Res 35:5

Nyakaana S, Arctander P (1998) Isolation and characterisation of microsatellite loci in the African elephant (Loxodonta africana). Mol Ecol 7:1436-1437
Nyakaana S, Okello JB, Muwanika V, Siegismund HR (2005) Six new polymorphic microsatellite loci isolated and characterized from the African savannah elephant genome. Mol Ecol Notes 2:233-235

Paetkau D, Calvert W, Stirling I, Strobeck C (1995) Microsatellite analysis of population structure in canadian polar bears. Mol Ecol 4:347-354

Paetkau D, Calvert W, Stirling I, Strobeck C (2004) Genetic assignment methods for the direct, real-time estimation of migration rate: a simulation-based exploration of accuracy and power. Mol Ecol 13:55-65

Vinay KS, Govindarajan R, Sita N, Anil K (2000) The effect of hairpin structure on pcr amplification efficiency. Mol Bio Today 1(3):67-69

Vira V, Ewing T (2014) Ivor y's Curse: The Militarization and Professionalization of Poaching in Africa<www.bornfreeusa. org $>$. Downloaded on 14 May 2014

Wasser SK, Shedlock AM, Comstock K, Ostrander EA, Mutayoba B, Stephens M (2006) Assigning African elephant DNA to geographic region of origin: applications to the ivory trade. PNAS 101:41 